\title{
DISADVANTAGES OF HERBACEOUS OIL-BEARING PLANTS AS FEEDSTOCK IN THE BIODIESEL PRODUCTION
}

Marija B. Tasić*

Faculty of Technology, University of Niš, Leskovac, Serbia

The cultivation of non-edible oil-bearing plants as feedstocks for the biodiesel production can aggressively take advantage of natural environments. Herbaceous non-edible oil-bearing plants have been significantly favored as an ideal feedstock for biodiesel fuel, though little is known about its industrial feasibility and environmental impact. The items with the greatest sensitivity in capital and ecology are land acquisition, plant life cycle, mechanical harvesting, fertilizer, control of weed, pests and diseases, seed yield and oil content. This study aims at analyzing the disadvantages of herbaceous non-edible oil-bearing plants and suggests impeding their industrial cultivation for the biodiesel production. The source of information for the proper selection of non-edible oil-bearing plants suitable as biodiesel feedstocks has been the recent relevant literature. Herbaceous non-edible oil-bearing plants have a low phytoremediation potential and oil yield, but high weed potential. They occupy a large arable area while demand harder cultivation conditions and mechanical harvesting. Non-edible oils from woody plants are promising biodiesel feedstock. However, the weed potential of woody oil-bearing plants must also be considered to prevent their invasiveness.
(REVIEW PAPER)

UDC 662.756.3: 633.85

DOI: $10.5937 /$ savteh2002088T

Keywords: biodiesel; non-edible oil; herbaceous oil-bearing plants; trees; phytoremediation; weed.

\section{Introduction}

The energy crisis is a burning global problem. The world's energy demands progressively rise while natural energy resources diminish since replenishing them takes centuries. Wars, deliberate manipulation with human society about over-consumption of goods, nationalization and privatization of energy companies cause a rising energy demand. To prevent an energy crisis, it is crucial to reduce the energy use and replace old with new, sustainable energy resources with a healthy life cycle of several decades. As a sustainable energy source, biodiesel drives attention in the scientific community for more than 60 years.

Moreover, the world population is becoming more environmentally aware, so the call for biodiesel is on the rise. The cost of biodiesel is the most influenced by the price of the feedstocks. Various feedstocks compete for the most suitable one, including oleaginous oil-bearing plants, microalgae, waste edible oils (WEO), agro-industrial seed waste (AISW) and rendered animal fats. A suitable biodiesel feedstock must supply high yields of non-edible, low-cost, monosaturated oil. Furthermore, its cultivation brings no risks to the natural environment [1]. In the light of economic and environmental issues, WEO $[2,3]$ and AISW are the most suitable biodiesel feedstocks, while the oil obtained from the seed of non-edible oil-bearing plants should be used only during shortfalls as a supplement [2].

Many herbaceous and woody non-edible oil-bearing plants have been tested as a potential supplement during
WEO and AISW shortfalls. The non-edible oil biorefinery concept is relatively new. Based on a Scopus search, the first appearance of non-edible oil-bearing plants (Jatropha curcas and Pongamia pinnata) as a biodiesel feedstock in technical journals was in 2006 [4]. It can be observed that the studies dealing with herbaceous are more dominant than those using woody non-edible oil-bearing plants. Thus, many published articles are focused on oil content, oil/biodiesel characterization, extraction techniques and transesterification. However, the choice of plant for the biodiesel production should not depend only on the properties of the oil or biodiesel but also on the economic and environmental impact of cultivating that oil-bearing plants.

This study compares various herbaceous and woody oil-bearing plants receiving enough attention to become feedstock in the biodiesel production. Our list is not comprehensive since 300 oil-bearing plants compete for the most suitable biodiesel feedstock. However, this study includes 64 oil-bearing plants receiving enough attention to be nominated as the ones with the highest potential to be used in the biodiesel production. The oil-bearing plants were assessed considering their inedibility, annual seed yield/availability, land occupation, cultivation/harvesting demands, lifecycle, phytoremediation and weed potential. For the selected nonedible oil-bearing plants, the land occupation for its cultivation was calculated based on arbitrarily selected biodiesel production capacity of 10000 tones/year. This review should

\footnotetext{
*Author address: Marija B. Tasić, Faculty of Technology, University of Niš, Bulevar oslobodjenja 124, 16000 Leskovac, Serbia

E-mail: marijat14@yahoo.com, mtasic@tf.ni.ac.rs

The manuscript received: October, 30, 2020.

Paper accepted: December, 03, 2020
} 
exemplify why some oil-bearing plants that are potentially invasive should not be speculatively planted for the biodiesel production. To the best author's knowledge, such a review paper covering the mentioned topics has not been published before.

\section{Inedibility of oil-bearing plants}

Non-edible oils are not for human consumption due to the presence of toxic components [5]. However, not all oils declared as non-edible contain known hazard effects and therefore are not very poisonous. For example, an oil obtained from Brassica carinata, herbaceous weed with phytoremediation potential, is edible [6,7], but it has been widely tested for the biodiesel production because its oil content is $33-38 \%$ [8]. Similar edible oil is obtained from the seed of weedy annual herbaceous Camelina sativa with phytoremediation potential [6,9-13]. Cuphea viscosissima contains up to $30 \%$ oil [14], of which $76 \%$ is capric acid, so it can replace palm kernel and coconut oil and be used in foods [15]. The oil obtained from Erica sativa (weed with phytoremediation potential) is a substitute for rapeseed oil [16]. Herbaceous annual Guizotia abyssinica has low phytoremediation potential [17], while seeds are the source of edible oil, a substitute for olive, rape and sesame oil [18]. Linum usitatissimum seed oil is edible too. This annual herbaceous plant is not a weed but has phytoremediation potential [19]. The seeds of Michelia champaca contain about $30 \%$ edible, semi-solid oil [20]. Herbaceous perennial Nicotiana tabacum is a plant with phytoremediation potential [21]. This plant seed oil can be edible after refining, besides being used in soap, paints, lubricants, fuel [22]. Herbaceous annual Onopordum acanthium is a weed with phytoremediation potential [23]. Its seeds provide an edible oil of good quality $[9,24]$. Ricinus communis oil is often used as a biodiesel feedstock due to toxic ricin in this weedy plant with phytoremediation potential. However, its oil is edible after ricin deactivation with heat or milk [25]. Silybum marianum seeds provide edible oil, often named as luxury and healthy food oil [26]. Solanum nigrum seed oil has high contents of linoleic acid and it can be used as frying oil [27]. Furthermore, fully ripe fruits of this plant can be eaten, too $[6,28,29]$.

Some seeds oil of herbaceous oil-bearing plants, such as Raphanus sativus var. oleifera, Thlaspi alliaceum, Asclepias syriaca, Portulaca oleracea, Cannabis sativa and Sinapis alba are rather named as non-edible. However, their seed is edible. Seeds of Raphanus sativus var. oleifera [24] and Asclepias syriaca [6] can be eaten raw or sprouted. Although Asclepias syriaca is a good phytoremediation candidate [30], it is an aggressive weed and poisonous to sheep, cattle and horses [31]. The powder od grounded Thlaspi alliaceum seeds is used as a mustard substitute [6,11], while sprouted seeds can be eaten as a salad [6]. Herbaceous annual weed with phytoremediation potential Portulaca oleracea L. produces oily seeds that can be used grounded into flour [6]. Annual herbaceous Cannabis sativa L. seed can be eaten raw or cooked. It can be parched and eaten as a condiment or made into cakes and fried [6,9,13,32]. Consuming large amounts of white mustard Sinapis alba seed can be danger- ous, but diluted by hot water, vinegar, salt, wine and other spices became a food flavoring [33]. Weed seeds of Thlaspi arvense are a mustard substitute or can be a salad ingredient $[6,11]$.

Similarly, not all woody oil-bearing plants can be used for the biodiesel production. Attalea speciosa tree is a weed, while seeds can be eaten raw, cooked, or made into nut milk. Seed oil can be used to make butter [34]. Phytoremediation potential woody weed of Balanites aegyptiaca [35] is also used as biodiesel feedstock due to the high oil content of $30-60 \%$. However, this oil is edible and used for cooking [36]. Edible oil can be obtained from the seeds of Bombax ceiba [6] and Caryocar coriaceum [34,37]. Ceiba pentandra tree produces seeds whose edible properties are suspicious. One report says that seeds could be eaten raw or cooked, roasted and ground into a powder in soups as a flavoring [6], while the other claims it is toxic [33]. However, a common opinion is that its oil is pleasant tasting and used for cooking $[6,33]$. Seeds and oil of Celastrus paniculatus abound in medicine. Kokam butter is made from seeds of Garcinia indica [6]. Seeds from phytoremediation tree Hevea brasiliensis contain cyanic acid which can be destroyed by soaking or boiling seeds for a prolonged period $[38,39]$ and used as food. Hibiscus sabdariffa is an annual/perennial shrub with phytoremediation potential [40]. Roasted seeds are a coffee substitute and when grounded into powder they could be used in oily soups and sauces $[6,13,18]$. Simarouba glauca is an evergreen tree, the fruit of which is edible, while seeds contain $60-75 \%$ of edible oil [41]. The seed of Sterculia foetida can be eaten [6,42] or a source of non-drying edible oil [43]. Zanthoxylum bungeanum is a shrub/tree in which fruit is a Sichuan pepper source, while the seed's oil (27\% $31 \%$ ) is considered a high nourishing and healthy edible [44]. Raw seeds of Ziziphus mauritiana can be eaten as a snack [45]. Macassar oil, obtained from seed of Schleichera oleosa may be used for human consumption but only after removing some cyanogenic compounds from it $[46,47]$.

Most biodiesel research studies deal with non-edible woody oils from Annona muricata [48], Annona squamosa [49], Idesia polycarpa var. vestita [50], Madhuca Iongifolia [51], Mesua ferrea [52], Salvadora persica [53], Ximenia americana [54]. However, these oils are derived from nonedible kernels seeds of edible fruits and therefore are classified as AISW.

The oil-bearing plants mentioned so far were in some way edible, and further discussion about their use in the biodiesel production is expelled. This review focuses on the non-edible oil-bearing plants (toxic) seed oil tested as a promising feedstock for the biodiesel production. Oil contents for woody oil-bearing plants Joannesia princeps, Melia azedarach, Putranjiva roxburghii, Samadera indica are of $37 \%, 40 \%, 43 \%$ and $33 \%$, respectively [55-58]. However, to the best author's knowledge, no seed yield information was available and therefore are not used in comparation for suitable biodiesel feedstock. The potential use of these oilbearing plants (Table 1) as alternative medicaments are also noticed. 
Table 1. Non-edible oil-bearing plants suitable for biodiesel production

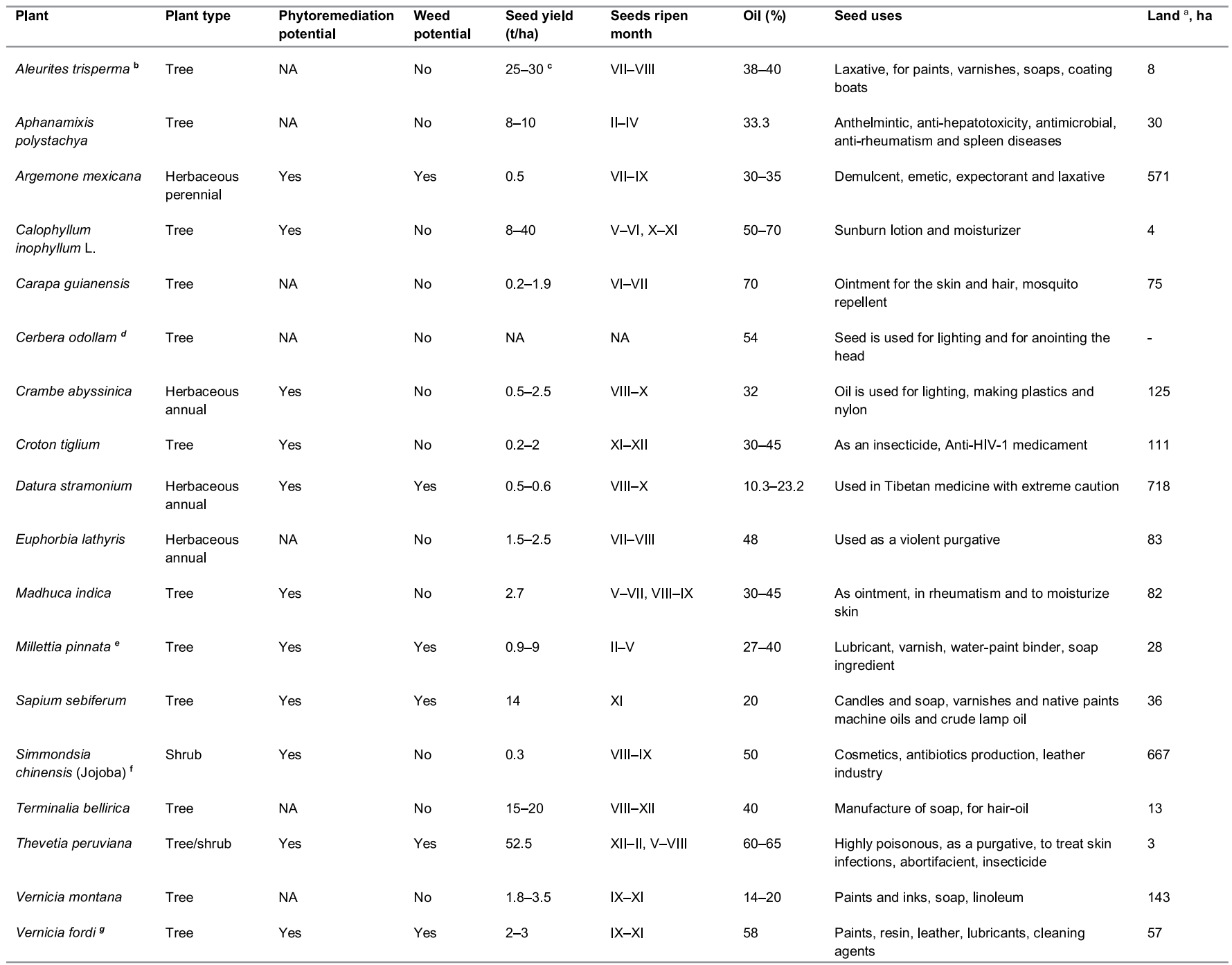

${ }^{a}$ Calculated for maximum seed yield, oil content, total conversion of oil and biodiesel production rate of 10000 t/year; ${ }^{b}$ Synonym of Reutealis trisperma; ${ }^{\mathrm{c}}$ Calculated from seeds/tree and tree/ha; ${ }^{\mathrm{d}}$ The species known as the suicide a
tree" is often confused with Cerbera manghas (Sea mango); ${ }^{\mathrm{e}}$ Also known as Pongamia glabra, Pongamia pinnata or Karanja; ${ }^{\ddagger}$ There is a debate on Jojoba seeds and oil use for human consumption; ${ }^{9}$ Also known as Tung tree.

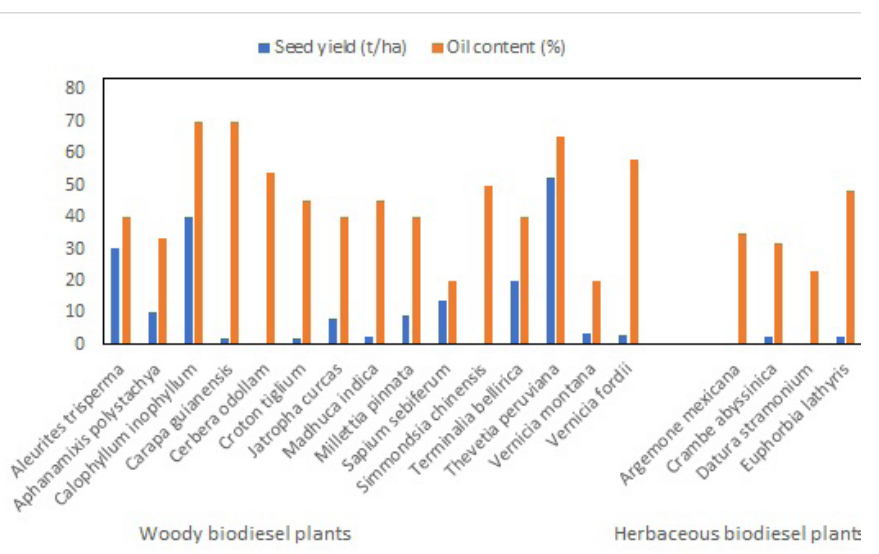

Figure 1. Woody vs. herbaceous non-edible plants for biodiesel production

\section{Seed yield and availability}

The highest seed yield of 52.5 tha was noticed with woody Thevetia peruviana [59]. Generally, both seed yield and oil content were higher in woody oil-bearing plants than in herbaceous (Figure 1). This could be the consequence of higher seeds weights of woody oil-bearing plants. The duration and period for seeds ripening are mostly the same, i.e., approximately two-three months, late spring, summer and early fall. The exception was trees Calophyllum inophyllum L., Jatropha curcas, Madhuca indica and Thevetia peruviana with more than one seed ripen seasons per year.

\section{Land occupation}

Proponents of the herbaceous non-edible oil biodiesel idea advocate marginal abandoned land to cultivate such oil-bearing plants with a minimum of fertilization and irrigation. Disadvantages in exploiting such scattered locations are high quality of planting seed material and lack of post-harvest technologies [60]. Also, herbaceous oil-bearing plants do not naturally occupy large, abounded areas suitable for mechanization, but the new arable area must be used for commercial sowing. Among selected oil-bearing plants (Table 1), woody needed smaller area for cultivation comparing to herbaceous types. It is because woody oil-bearing plants pro- 
vide higher seed yields and the oil content. The vast land occupation was noticed for Jojoba, which made this tree inappropriate as biodiesel feedstock. On the other side, Calophyllum inophyllum and Thevetia peruviana trees needed the smallest cultivation area. However, seed ripening season for both woody oil-bearing plants is annually twice, which may increase its price of harvesting. Among herbaceous oil-bearing plants, Euphorbia lathyrism needed the smallest cultivation area of 83 ha.

Instead of using marginal lands, another scientific community suggests a plant rotation technique where the same land can be used for different plant cultivation. A rotation technique improves the soil condition and plant nutrition, influencing the increased yield, quality and a reduced pest pressure. However, negative aspects of the plant rotation are often overlooked [61]. Cultivating two or more oil-bearing plants on one site means building a system. It is complicated for the system to maintain the different time of propagation, flowering, seed ripping, the excess or decreased fertility, increased or decreased pest pressure, herbicide residues, the same soil compaction. For these reasons, farmers can have a lowered income of the plant yield and quality. For example, Cuphea viscosissima can be in rotation cultivation with corn every three years. It has been suggested that Cuphea viscosissima breaks the rootworm cycle, so corn yields increase. However, Cuphea viscosissima shows to be intolerant to stress since it stopped growing [62], or its roots can provide the rootworm larval development [63]. Wheat can be in plant rotation with Argemone mexicana. However, the wheat yield losses of $17 \%$ and $22 \%$ have been noticed [64]. Crambe abyssinica can be cultivated in rotation with soybean [65] to suppress the growth of weed and fertilize the soil. However, it was shown that other oil-bearing plants, such as radish (Raphanus sativus) could suppress higher amounts of weed, while the absolute deposited amount of straw (post-harvest dry mass, deposited on the soil surface which stood as a good fertilizer) was obtained at the area with Brachiaria ruziziensis [66]. Datura stramonium is a weed, so its use in plant rotation cultivation was not recorded. Rotation technique cultivation of Euphorbia lathyris was mentioned as a possibility [67], while its further investigation is missing. Rotation cultivation among woody oil-bearing plants was noticed with shrubs and grasses. Croton tiglium is rotated with cacao or coffee to provide shade [18]. Woody Madhuca indica, Pongamia pinnata and Azardirachta indica are intercropped with Ricinus communis (shrub) and grasses like Miscanthus giganteus and Panicum virgatum [68].

\section{Cultivation and harvesting}

Water requirements, fertile soil and pests/disease control strategies increase the biodiesel plant cultivation costs. As it can be seen (Table 2), both herbaceous and woody oil-bearing plants required regular irrigation. The application of fertilizers was not noticed only among two woody oil-bearing plants Aphanamixis polystachya and
Calophyllum inophyllum L., while other oil-bearing plants grew better with fertilizers. Organic fertilizers were the most common, such as farmyard manure [69] and green manure plants [70]. Seed cakes of Madhuca longifolia, Pongamia pinnata, Azadirachta indica and Ricinus communis, can be applied as fertilizers [71] during the Terminalia bellirica growth. Besides Aleurites trisperma [72], Aphanamixis polystachya [73], Datura stramonium [74] and Millettia pinnata [18], most of the oil-bearing biodiesel plants were the host for recognized pests and pathogens and numerous insect attacks.

Harvesting techniques of herbaceous oil-bearing plants used in the biodiesel production could mainly be mechanized. An exception is manual collecting of Argemone mexicana seed, which must be taken with caution since it is poisonous and irritating [75]. Combineharvester with the available equipment for cereal can be used for Crambe abyssinica harvesting [76]. Datura stramonium can be harvested with hay or silage. Standard harvesting equipment is applied. Euphorbia lathyris harvesting by combine is not yet reported.

Millettia pinnata can be mechanically harvested with a Colossus harvester [77]. Vernicia fordii seeds are harvested by field labor or mechanical methods [78]. Except for these two woody plants, harvesting of the rest of the woody plants is manual. The maturated fruit of Aleurites trisperma drops to the ground so its harvesting method is by hand [79]. Calophyllum inophyllum seeds are usually harvested after mature fruits fall to the ground, but picking, lopping off branches with pruning poles are also recorded [80]. Human harvesting by picking seeds of Carapa guianensis from the ground has also been noticed [81]. However, a desiccant must be applied before harvesting to avoid difficulties in collecting and cleaning the seeds. Currently, the harvesting of Jatropha curcas fruits is mainly manual [82]. Madhuca indica and Terminalia bellirica harvesting technique is handpicking [83]. However, due to the increased market demand, illegal, destructive ways of lopping and cutting fruits-bearing twigs replaced traditional ones. Fruits and seeds of Sapium sebiferum are harvested by hand when leaves have fallen [18]. Simmondsia chinensis can be harvested by implementing various methods, such as raking from under the bushes followed by suction, pruning the lower branches and handpicking [18]. Harvesting of the fallen fruits by hand and picking from the trees are the most common methods of collecting Vernicia montana seeds in China [84]. However, harvesting is not complicated since it represents fruit collection from the ground. Also, mechanized harvesting could be implemented very easily since fruit picking machines could be used.

Quantitative data on harvesting methods of Aphanamixis polystachya, Cerbera odollam, Croton tiglium, and Thevetia peruviana harvesting seeds lack in the literature, probably since seeds of these trees were not commercially used. 
Table 2. Conditions for non-edible oil-bearing plants cultivation

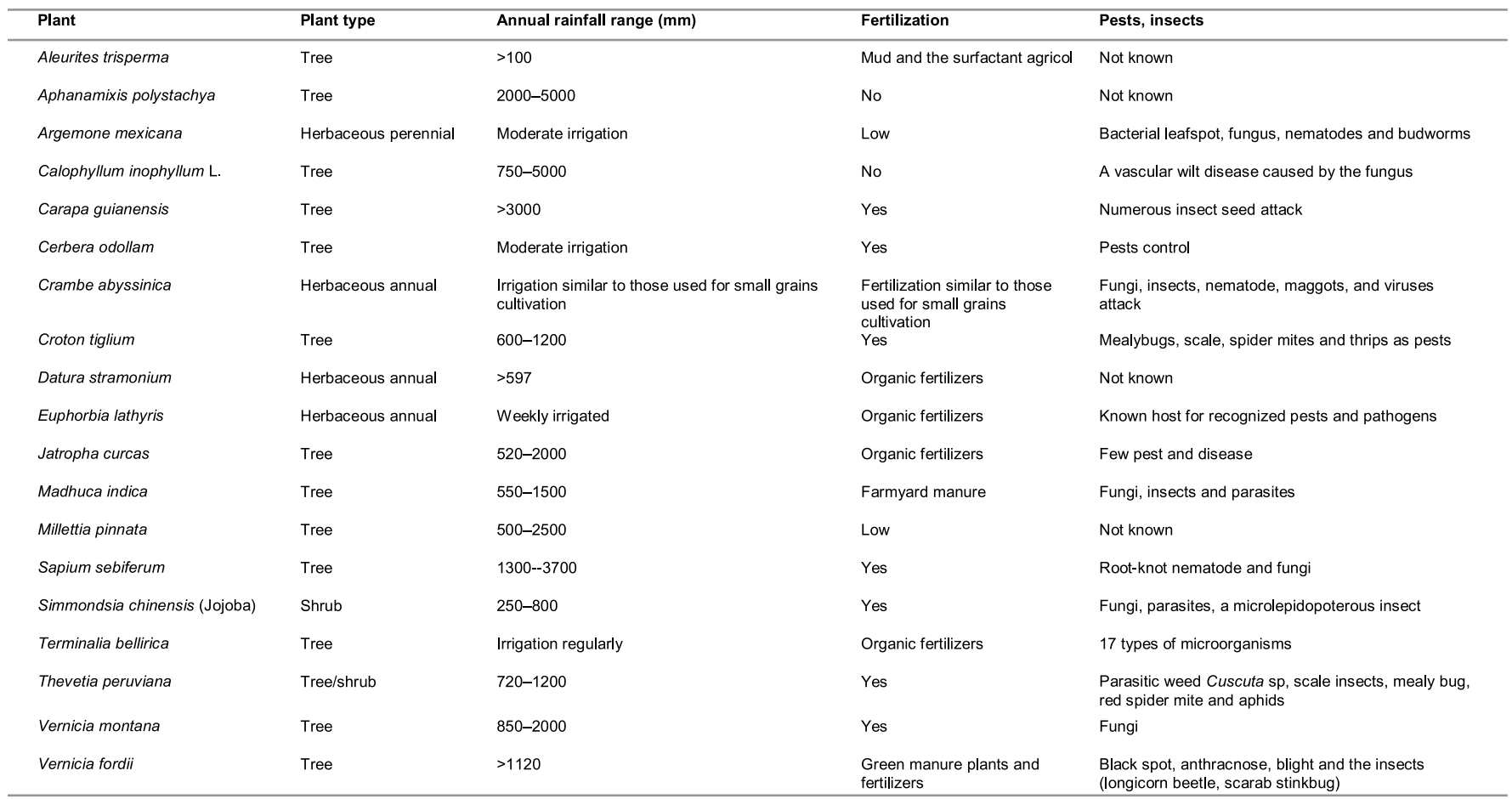

\section{Plant lifecycle}

Most of the herbaceous oil-bearing plants used as a biodiesel feedstock are annual (Table 1 and 2), which means they need to be replanted from seed on marginal land every year or in rotation with other plants every second, third year. Replantation of this short lifecycle oil-bearing plants increases cultivation costs. Annual and perennial oil-bearing plants grow faster than trees. Argemone mexicana sowing takes place in spring and the seeds can be ripen from July to September. Crambe abyssinica is cultivated as a spring-sown plant while the seed can be harvest in late summer. Datura stramonium and Euphorbia lathyris annual oil-bearing plants take five and six months from sowing to harvesting the seeds, respectively [85]. These annual herbaceous oil-bearing plants grow faster than trees, but not among other edible plants. For example, Euphorbia lathyris is challenging to grow without irrigation and its growth is very slow, twice slower than sunflower [67].

On the other hand, trees are long living, with a lifecycle of more than forty years. Trees provide soil support, shade for grazing animals, trapped air dust and reduced wind/rain damaging effects. The growth of trees is slow during the first three years of life, and trees are not hermaphrodites. Seedling and trees raised from root suckers bear fruits (seeds) after 5 to 6 and 7 to 9 years from planting, respectively. A faster option in instant biodiesel production would be to use the existing seeds capacities of already planted trees. The growth rate of the evergreen tree of Aleurites trisperma is fast but the first seeds can be collected 8 to 10 years after planting [72]. Aphanamixis polystachya evergreen tree growth is rapid [86] and it is flowering 3-4 years after plantation [87], pro- viding the fruits and seeds. The growth rate of Calophyllum inophyllum is slow and gives fruits (seeds) at the 10 years of life [88]. Carapa guianensis tree is fast-growing and generally begin to fruit during 10-12 years old $[81,89]$. Croton tiglium plants take three years from sowing to harvesting the seed $[90,91]$. Jatropha curcas average full seed productivity is at about 3 years, while under preferred rainfall conditions, it can be after the second rainy season [46,92]. The Mahuna indica starts bearing 8 to 15 years from plantation [93]. The growth of young trees of Millettia pinnata is relatively slow, but seed production starts when trees are 5 - 7 years old $[46,94]$. A fast-growing tree of Sapium sebiferum requires from 3 - 8 years to bear seeds $[18,95]$. The jojoba growth rate is a slow tree and provides full bearing in $7-8$ years from plantation [96]. The harvesting time of Terminalia bellirica seed is done after 7-8 years of growth [97]. Vernicia montana gives seeds in a 3 -year-old period [84]. Vernicia fordii start bearing fruit the third year after planting, with the maximum production in 10 - 12 years [70].

\section{Phytoremdiantion and weedy potential}

Most oil-bearing plants listed in Table 1 are bioaccumulators of heavy metals and some toxic substances, so they are used in phytoremediation. Weed plants are soil bioindicators, as well. The trees have higher accumulation capacities because of the extensive and deep rooting system [98]. Furthermore, trees have a long lifecycle to constantly remediate soil for a long time, for example, at barren tailing dumps. Argemone mexicana uptake heavy metal by entire plant parts [99]. Eight months old seedlings of Calophyllum inophyllum accumulate lead and copper [100], while Crambe abyssinica leaves have 
an excellent potential in arsenic phytoremediation [18]. The efficient cadmium, mercury, and zinc phytoremediation plant is Croton tiglium. The order of these heavy metals' sensitivity towards the roots, stem and leaves of this plant is zinc > cadmium > mercury [101]. Seedlings of Datura stramonium contains cadmium [102]. After the 90-day phytoremediation, the roots, stems and leaves remove iron and arsenic from the soil mixture [103]. Simultaneously, heavy metals are not detected in the Jatropha seeds, implying no metal emissions from such biodiesel [104]. The roots of most of the Madhuca indica accumulate a higher concentration of chromium, nickel, and cadmium [105]. Millettia pinnata accumulates copper in seed coats from $1220 \mathrm{ppm}$ to $26 \mathrm{ppm}$ [106]. Sapium sebiferum contains mercury and zinc in its roots [107]. The phytoremediation potential of Simmondsia chinensis biomass is reported by cobalt, copper, nickel and iron [108]. Chromium followed by lead and nickel are found in leaves and roots of Thevetia peruviana [109].

Although numerous papers deal with phytoremediation with oil-bearing plants, which could be used in the biodiesel production, the influence of such a contaminated soil on the heavy metal presence and concentration in seeds and derived oils is contradictory. Bauddh et al. [110] report a low concentration of metals in oil seeds, but contaminated oil's combustion is not clearly explained. Other authors report that phytoremediation does not improve the environmental situation since heavy metals concentrations in seeds are above the maximum allowed and hazardous metal emissions from biodiesel are questionable [111].

No commercial cultivation of weedy oil-bearing plants is advised for the biodiesel production. Weeds are harmful to the environment because they are hard to control, alter the habitats and lead non-invasive species into extinction. Birds and wind are spreading the seeds, while mechanically harvesting rarely exists. The lack of risk assessments for weed plants used in the biofuels production is already criticized [112,113]. Furthermore, Australia loses $\$ 4$ billion annually to cultivate weedy biodiesel Mimosa pigra, while Rubber vine takes $\$ 27$ million every year [114]. Based on Table 1, only Euphorbia lathyris posed no weed threat among herbaceous oil-bearing plants. Woody oil-bearing plants, such as Jatropha curcas, Millettia pinnata, Sapium sebiferum, Thevetia peruviana and Vernicia fordii, often promoted as the ideal biodiesel plants, were weeds, too.

\section{Conclusions}

In a world affected by various environmental disasters, biodiesel feedstock sources should be WEO, AISW and rendered animal fats. During shortfalls, oil obtained from non-edible oil-bearing plants could be used as a supplement. The woody oil-bearing plants were recommended as they provide a higher yield and oil content than herbaceous oil-bearing plants. However, the drawback was hand seed harvesting. Trees occupied small marginal land areas, with low or without fertilization support. Rainfalls were the only type of required irrigation for woody oil-bearing plants. Some trees were without pests/disease control strategies. Trees have a slow but long lifecycle. Furthermore, trees were gaining momentum over herbaceous plants in phytoremediation trials because of their greater effectiveness. However, further studies must be performed to determine if and how much heavy metals would be accumulated in seeds. What concerns attention was that some of the listed biodiesel woody oil-bearing plants had a substantial history as weeds. Therefore, weed risk must be assessed to ensure that woody oil-bearing plants do not add biodiesel to the invasive species fire.

\section{Acknowledgments}

This work was supported by the Ministry of Education, Science and Technological Development of the Republic of Serbia under the Program of financing scientific research work, number 451-03-68/2020-14/200133.

\section{References}

[1] K. Tyson, J. Brown, M. Moora, Industrial mustard crops for biodiesel and biopesticides, Golden, CO, 2000.

[2] M.M. Gui, K.T. Lee, S. Bhatia, Feasibility of edible oil vs. non-edible oil vs. waste edible oil as biodiesel feedstock, Energy, 33 (2008) 1646-1653.

[3] C. Macombe, P. Leskinen, P. Feschet, R. Antikainen, Social life cycle assessment of biodiesel production at three levels: A literature review and development needs, Journal of Cleaner Production, 52 (2013) 205-216.

[4] R. Kumar, M. Sharma, S.S. Ray, A.S. Sarpal, A.A. Gupta, D.K. Tull, R. Sarin, R.P. Verma, N.R. Raje, Biodiesel from Jatropha curcas and Pongamia Pinnata, in: SAE Technical Papers, SAE International, 2004.

[5] I.B. Banković-llić, O.S. Stamenković, V.B. Veljković, Biodiesel production from non-edible plant oils, Renewable and Sustainable Energy Reviews, 16 (2012) 3621-3647.

[6] S. Facciola, Cornucopia II: A Source Book of Edible Plants, 2nd ed., Kampong Publications, 1998.

[7] L. Marchiol, S. Assolari, P. Sacco, G. Zerbi, Phytoextraction of heavy metals by canola (Brassica napus) and radish (Raphanus sativus) grown on multicontaminated soil, Environmental Pollution, 132 (2004) 21-27.

[8] R. Blackshaw, E. Johnson, Y. Gan, W. May, D. McAndrew, V. Barthet, T. McDonald, D. Wispinski, Alternative oilseed crops for biodiesel feedstock on the Canadian prairies, Canadian Journal of Plant Science, 91 (2011) 889-896.

[9] E.L. Sturtevant, U.P. Hedrick, Sturtevant's edible plants of the world, Dover Publications, 1972.

[10] A.R. Clapham, T.G. Tutin, E.F. Warburg, Flora of the British Isles, ed. 2, Cambridge University Press, New York, 1962.

[11] T. Tanaka, Cyclopedia of Edible Plants of the World, 1976.

[12] J. Rosengarten, F., The book of edible nuts., Walker and Company, New York, 1984.

[13] G. Kunkel, Plants for human consumption, Koeltz Scientific Books, Koenigstein, 1984.

[14] W.W. Roath, M.P. Widrlechner, R. Kleiman, Morphological and agronomic variability in Cuphea viscosissima Jacq, Industrial Crops and Products, 1 (1992) 5-10. 
[15] R. Kleiman, Chemistry of new industrial oilseed crops, in: J. Simon, J.E. Simon (Eds.), Advances in New Crops, Timber Press, Portland, OR, 1990: pp. 196-203.

[16] G.B. Masefield, M. Wallis, S.G. Harrison, B.E. Nicholson, eds., The Oxford Book Of Food Plants, 1st Ed, Oxford University Press, London, 1975.

[17] H. Amin, B. Ahmed Arain, M.S. Abbasi, F. Amin, T.M. Jahangir, N. ul A. Soomro, Evaluation of chromium phytotoxicity, phyto-tolerance, and phyto-accumulation using biofuel plants for effective phytoremediation, International Journal of Phytoremediation, 21 (2019) 352-363.

[18] J.A. Duke, Handbook of energy crops, Purdue University, Center for New Crops \& Plants Products, 1983.

[19] M.H. Saleem, S. Ali, S. Hussain, M. Kamran, M.S. Chattha, S. Ahmad, M. Aqeel, M. Rizwan, N.H. Aljarba, S. Alkahtani, M.M. Abdel-Daim, Flax (Linum usitatissimum L.): A potential candidatfor phytoremediation? biological and economical points of view, Plants, 9 (2020) 496.

[20] U. Dasuki, M.S. Kuswanto, Michelia L. (PROSEA), PlantUse English, (2016).

[21] V. Angelova, Phytoremediation potential of enhanced tobacco in soil contaminated with heavy metals, in: 2nd International Scientific Conference ITEMA, Graz, Austria, 2018: pp. 1049-1057.

[22] S. Faugno, L. del Piano, M. Crimaldi, G. Ricciardiello, M. Sannino, Mechanical oil extraction of Nicotiana tabacum L. Seeds: Analysis of main extraction parameters on oil yield, Journal of Agricultural Engineering, 47 (2016) 142147.

[23] A. Karimi, H. Khodaverdiloo, Fungi and bacteria as helping agents for remediation of a $\mathrm{Pb}$ - contaminated soil by Onopordum acanthium, Caspian Journal of Environmental Sciences, 15 (1999) 249-263.

[24] R. Phillips, N. Foy, Herbs, Pan Macmillan, 1990.

[25] R. Rasooly, X. He, M. Friedmans, Milk inhibits the biological activity of ricin, Journal of Biological Chemistry, 287 (2012) 27924-27929.

[26] C.S. Chambers, V. Holečková, L. Petrásková, D. Biedermann, K. Valentová, M. Buchta, V. Křen, The silymarin composition... and why does it matter???, Food Research International, 100 (2017) 339-353.

[27] J.R. Dhellot, E. Matouba, M.G. Maloumbi, J.M. Nzikou, M.G. Dzondo, M. Linder, M. Parmentier, S. Desobry, Extraction and nutritional properties of Solanum nigrum L seed oil, African Journal of Biotechnology, 5 (2006) 987-991.

[28] D. Frohne, H. Jürgen Pfänder, A colour atlas of poisonous plants: A handbook for pharmacists, doctors, toxicologists, and biologists, Wolfe, 1984.

[29] A. Crowe, Native Edible Plants of New Zealand, 1st ed., Hodder Moa Beckett Publishers Ltd, 1991.

[30] A. Stingu, I. Volf, V.I. Popa, I. Gostin, New approaches concerning the utilization of natural amendments in cadmium phytoremediation, Industrial Crops and Products, 35 (2012) 53-60.

[31] USDA ARS, Milkweed (Asclepias spp.): USDA ARS, (n.d.).

[32] H.D. Harrington, Edible Native Plants of the Rocky Mountains, University of New Mexico Press, 1974.

[33] D. Bown, Encyclopaedia of Herbs and their Uses, Dorling Kindersley, London, 1995.

[34] H. Lorenzi, Brazilian Trees: A Guide to the Identification and Cultivation of Brazilian Native Trees, 4th ed, Instituto Plantarum de Estudos da Flora, 2002.
[35] P. Parmar, B. Dave, K. Panchal, R.B. Subramanian, Identification of Potential Species Croton bonplandianum, Sedges and Balanitis aegyptiaca for the Application of Phytoremediation, American Journal of Plant Sciences, 4 (2013) 1246-1251.

[36] A.A. Mariod, M.E. Saeed Mirghani, I. Hussein, Balanites aegyptiaca Seed Oil, in: Unconventional Oilseeds and Oil Sources, Elsevier, 2017: pp. 157-166.

[37] G.T. Prance, M. Freitas da Silva, Caryocaraceae, New York Botanical Garden Press, Organization for Flora Neotropica, UNESCO, New York, 1973.

[38] M. Barwick, Tropical \& Subtropical Trees: A Worldwide Encyclopaedic Guide, Thames \& Hudson, London, United Kingdom, 2004.

[39] M.J.M. Yusof, M.T. Latif, S.F.M. Yusoff, Heavy metals phytoremediation potential of Hevea brasiliensis in Bentong, Malaysia, in: AIP Conference Proceedings, American Institute of Physics Inc., 2018: p. 20089.

[40] M. Nizam Uddin, Phytoremediation Potentiality of Lead from Contaminated Soils by Fibrous Crop Varieties, American Journal of Applied Scientific Research, 2 (2016) 22.

[41] P.C. Standley, J.A. Steyermark, Flora of Guatemala, by Paul C. Standley and J.A. Steyermark., [s.n.], Chicago, 1946.

[42] N.P. Manandhar, Plants and People of Nepal, Timber Press, 2002.

[43] J. Uphof, Dictionary of economic plants, J. Cramer, Weinheim, 1959.

[44] T. Liu, S. yong Yao, Z.Y. Yin, X.X. Zheng, Y. Shen, Study on preparation method of Zanthoxylum bungeanum seeds kernel oil with zero trans-fatty acids, Environmental Science and Pollution Research, 23 (2016) 7132-7137.

[45] C.K. Ruffo, A. Birnie, B. Tengnas, Edible Wild Plants of Tanzania, Regional Land Management Unit, Nairobi; Kenya, 2002.

[46] World Agroforestry, ICRAF, (1978).

[47] C. Marsh, G. Sobol, W. Stayte, E. Sears, P. Harding, Schleichera oleosa - (Lour.) Oken., Plants for a Future (PFAF), (2008).

[48] W.L. Wong, W.H. Lim, J. Si, M.K. Lam, Y.C. Ho, Production of biodiesel from Annona muricata seeds, in: E3S Web of Conferences, EDP Sciences, 2019: p. 1011.

[49] S.R. Hotti, O.D. Hebbal, Biodiesel Production Process Optimization from Sugar Apple Seed Oil ( Annona squamosa ) and Its Characterization, Journal of Renewable Energy, 2015 (2015) 1-6.

[50] F.X. Yang, Y.Q. Su, X.H. Li, Q. Zhang, R.C. Sun, Preparation of biodiesel from Idesia polycarpa var. vestita fruit oil, Industrial Crops and Products, 29 (2009) 622-628.

[51] Y. Mani, T. Devaraj, K. Devaraj, S.A. AbdurRawoof, S. Subramanian, Experimental investigation of biodiesel production from Madhuca longifolia seed through in situ transesterification and its kinetics and thermodynamic studies, Environmental Science and Pollution Research, 27 (2020) 36450-36462.

[52] A.P. Bora, S.H. Dhawane, K. Anupam, G. Halder, Biodiesel synthesis from Mesua ferrea oil using waste shell derived carbon catalyst, Renewable Energy, 121 (2018) 195-204.

[53] M. Ali, B. Naqvi, I.A. Watson, Possibility of converting indigenous Salvadora persica L. seed oil into biodiesel in Pakistan, International Journal of Green Energy, 15 (2018) 427-435.

[54] R. Alves Carvalho da Silva, T. Leda Gomes de Lemos, 
D. Alves Ferreira, F. José Queiroz Monte, Chemical study of the seeds of Ximenia americana: Analysis of methyl esters by gas chromatography coupled to mass spectrometry, Journal of Analytical \& Pharmaceutical Research, 7 (2018).

[55] K. Fern, Joannesia princeps, Useful Tropical Plants Database, (2014).

[56] K. Fern, Melia azedarach, Useful Tropical Plants Database, (2014).

[57] K. Fern, Putranjiva roxburghii, Useful Tropical Plants Database, (2014).

[58] K. Fern, Samadera indica, Useful Tropical Plants Database, (2014).

[59] A. Kumar, S. Sharma, Potential non-edible oil resources as biodiesel feedstock: An Indian perspective, Renewable and Sustainable Energy Reviews, 15 (2011) 1791-1800.

[60] A.E. Atabani, A.S. Silitonga, H.C. Ong, T.M.I. Mahlia, H.H. Masjuki, I.A. Badruddin, H. Fayaz, Non-edible vegetable oils: A critical evaluation of oil extraction, fatty acid compositions, biodiesel production, characteristics, engine performance and emissions production, Renewable and Sustainable Energy Reviews, 18 (2013) 211-245.

[61] J.B. Sieczka, Some Negative Aspects of Crop Rotation, in: Effects of Crop Rotation on Potato Production in the Temperate Zones, Springer Netherlands, 1989: pp. 259272.

[62] S. Retka Schill, Taming the Wild Cuphea | Biomassmagazine.com, Biomass Magazine, (n.d.).

[63] R.W. Behle, T.A. Isbell, Evaluation of Cuphea as a rotation crop for control of western corn rootworm (Coleoptera: Chrysomelidae), Journal of Economic Entomology, 98 (2005) 1984-1991.

[64] S. Manalil, B.S. Chauhan, Interference of turnipweed (Rapistrum rugosum) and Mexican pricklepoppy (Argemone mexicana) in wheat, Weed Science, 67 (2019) 666-672.

[65] R. Ferreira Santos, O. Henrique Viana, L. Kazue Tokura, D. Secco, C. Fernando Lewandoski, P. de Lima Bueno, O. Hideo Ando Junior, M. Prior, H. José Alves, Assessment of a crambe (Crambe abyssinica Hochst) crop under no-tillage in different sowing dates, African Journal of Agricultural Research, 11 (2016) 3690-3695.

[66] G. Concenço, C.J. Silva, M. Tomazi, I.V.T. Correia, N.C.D.S. Souza, A. Andres, Infestação de espécies de plantas daninhas em pré-plantio de soja em sistema de sucessão a culturas de inverno, Planta Daninha, 31 (2013) 551-558.

[67] R.M. Sachs, C.B. Low, J.D. Macdonald, A.R. Awad, M.J. Sully, Euphorbia lathyris: a potential source of petroleum like products, California Agriculture, (1981) 29-32.

[68] V. Tripathi, S.A. Edrisi, P.C. Abhilash, Towards the coupling of phytoremediation with bioenergy production, Renewable and Sustainable Energy Reviews, 57 (2016) 1386-1389.

[69] S. Lele, Mahua / Madhuca Indica, (n.d.).

[70] C. Marsh, G. Sobol, W. Stayte, E. Sears, P. Harding, Vernicia fordii - (Hemsl.) Airy Shaw, Plants for a Future (PFAF), (2008).

[71] C. V. Naidu, P.M. Swamy, Effect of seed oil cakes as fertilizer on growth and biomass production of Terminalia bellerica (Gaertn.) Roxb., Indian Forester, 120 (1994) 1084-1088.

[72] N.O. Aguilar, L.P.A. Oyen, Reutealis trisperma (PROSEA), PlantUse English, (2016).
[73] C. Chimera, Aphanamixis polystachya (Meliaceae), Puunene, Hawaii, 2012.

[74] S. Alinejad, V. Sarabi, A.R.S. Bakhtvari, H. Hashempour, Variation in physiological traits, yield and secondary metabolites of jimsonweed (Datura stramonium L.) under different irrigation regimes and nutrition systems, Industrial Crops and Products, 143 (2020) 111916.

[75] C.H. Bosch, Argemone mexicana L., PROTA (Plant Resources of Tropical Africa / Ressources Végétales de l'Afrique Tropicale), (2007).

[76] D. Samarappuli, F. Zanetti, S. Berzuini, M.T. Berti, Crambe (Crambe abyssinica Hochst): A Non-Food Oilseed Crop with Great Potential: A Review, Agronomy, 10, 1380 (2020) 18.

[77] A. Abadi, H. Maynard, N.L. Arpiwi, C. Stucley, J. Bartle, R. Giles, Economics of Oil Production from Pongamia (Millettia pinnata) for Biofuel in Australia, Bioenergy Research, 9 (2016) 874-883.

[78] T. Rinehart, J. Shockey, N. Edwards, J.M. Spiers, T. Klasson, Vernicia fordii "Spiers", a New Tung Tree for Commercial Tung Oil Production in the Gulf Coast Region, Hort Science, 50 (2015) 1830-1832.

[79] G.H. Blackmon, The tung-oil industry, The Botanical Review, 9 (1943) 1-40.

[80] N. Krishnakurnar, K. Palanisamy, M. Hegde, K.C.S. Warrier, M. Krishnarnoorthy, Manual of Econornically Important Forestry Species in South India, Coimbatore, Tamil Nadu, India, 2010.

[81] C. Plowden, The Ecology and Harvest of Andiroba Seeds for Oil Production in the Brazilian Amazon, Conservation and Society, 2 (2004) 251.

[82] M. Forleo, N. Palmieri, Harvesting techniques of Jatropha curcas L. and economic sustainability, in: 25th European Biomass Conference: Setting the Course for a Biobased Economy, Stockholm, 2017: pp. 298-301.

[83] C.P. Kala, Indigenous uses and sustainable harvesting of trees by local people in the Pachmarhi Biosphere Reserve of India, Int. J. Med. Arom. Plants, 1 (2011) 153-161.

[84] L.P.. Oyen, Vernicia montana (PROTA), PlantUse English, (2015).

[85] C. Marsh, G. Sobol, W. Stayte, E. Sears, P. Harding, Plant database, Plants for a Future (PFAF), (2008).

[86] Y. Rai, Growth and Development of Medicinal Endangered Tree Species Aphanamixis polystachya (Wall.) Parker in District Meerut, (U.P.) India, International Journal of Multidisciplinary and Current Research, 2 (2014) 1.

[87] Bio Fuel Park, Aphanamixis polystachya (Wall.) R. Parker, The Department of Forestry and Environmental Science, University of Agricultural Sciences, GKVK Bengaluru, (2010).

[88] K. Fern, Calophyllum inophyllum, Useful Tropical Plants Database, (2014).

[89] M.A.B. Camargo, R.A. Marenco, Growth, leaf and stomatal traits of crabwood (Carapa guianensis Aubl.) in central Amazonia, Revista Arvore, 36 (2012) 7-16.

[90] A.K. Singh, S.D. Fernando, Reaction Kinetics of Soybean Oil Transesterification Using Heterogeneous Metal Oxide Catalysts, Chemical Engineering \& Technology, 30 (2007) 1716-1720.

[91] K. Fern, Croton tiglium, Useful Tropical Plants Database, (2014).

[92] C. Marsh, G. Sobol, W. Stayte, E. Sears, P. Harding, Jatropha curcas - L., Plants for a Future (PFAF), (2008).

[93] CJP, Mahua :Madhuca indica - A new source of biodiesel, 
Advanced Biofuel Center, (2020).

[94] C. Marsh, G. Sobol, W. Stayte, E. Sears, P. Harding, Pongamia pinnata - (L.) Pierre, Plants for a Future (PFAF), (2008).

[95] C. Brickell, The RHS Gardener's Encyclopedia of Plants and Flowers, Dorling Kindersley Publishers Ltd, UK, 1989

[96] C. Marsh, G. Sobol, W. Stayte, E. Sears, P. Harding, Simmondsia chinensis - (Link) C.K.Schneid, Plants for a Future (PFAF), (2008).

[97] Regional Centre for Development Cooperation (RCDC), Banajata, (2020).

[98] L. Gómez, A. Contreras, D. Bolonio, J. Quintana, L. Oñate-Sánchez, I. Merino, Phytoremediation with trees, in: Advances in Botanical Research, Academic Press Inc., 2019: pp. 281-321.

[99] M. Gautam, M. Agrawal, Identification of metal tolerant plant species for sustainable phytomanagement of abandoned red mud dumps, Applied Geochemistry, 104 (2019) 83-92.

[100] N. Chaturvedi, N.K. Dhal, P.S.R. Reddy, Comparative phytoremediation potential of Calophyllum inophyllum L., Bixa orellana L. and Schleichera oleosa (lour.) Oken on iron ore tailings, International Journal of Mining, Reclamation and Environment, 26 (2012) 104-118.

[101] N. Vr, M. Sr, Macrophytes as a heavy metal scavengers at MIDC effluent stream, 2013.

[102] Z. Shirkhani, A. Chehregani Rad, M. Gholami, F. Mohsenzadeh, Phytoremediation of Cd-contaminated soils by Datura stramonium L., Toxicology and Environmental Health Sciences, 10 (2018) 168-178.

[103] J.F. García Martín, M. del C. González Caro, M. del C. López Barrera, M. Torres García, D. Barbin, P. Álvarez Mateos, Metal accumulation by Jatropha curcas L. adult plants grown on heavy metal-contaminated soil, Plants, 9 (2020) 418.

[104] N. Aggangan, N. Cadiz, A. Llamado, A. Raymundo, Jatropha Curcas for bioenergy and bioremediation in mine tailing area in Mogpog, Marinduque, Philippines, in: Energy Procedia, Elsevier Ltd, 2017: pp. 471-478.

[105] S. Sahoo, Phytoremediation potential of some native plants growing in the vicinity of sponge iron industry, Pollution Research, 36 (2017) 333-339.

[106] M.V.R. Prasad, Environmental Amelioration through Pongamia pinnata based Phytoremediation, International Journal of Science and Research, 8 (2018).

[107] C. Tang, Y. Chen, Q. Zhang, J. Li, F. Zhang, Z. Liu, Effects of peat on plant growth and lead and zinc phytostabilization from lead-zinc mine tailing in southern China: Screening plant species resisting and accumulating metals, Ecotoxicology and Environmental Safety, 176 (2019) 42-49.

[108] R. Sharma, R. Bhardwaj, V. Gautam, S. Bali, R. Kaur, P. Kaur, M. Sharma, V. Kumar, A. Sharma, Sonia, A.K. Thukral, A.P. Vig, P. Ohri, Phytoremediation in waste management: Hyperaccumulation diversity and techniques, in: Plants Under Metal and Metalloid Stress: Responses, Tolerance and Remediation, Springer Singapore, 2018: pp. 277-302.

[109] N. Sood, J. Kaur, G. Singh, Quantitative determination of heavy metal pollution in soil and different plant parts of thevetia peruviana for phytoaccumulation determination at different locations in kurukshetra city, haryana, Journal of Environmental and Applied Bioresearch, 4 (2016) 4348.
[110] K. Bauddh, B. Singh, J. Korstad, Phytoremediation potential of bioenergy plants, Springer Singapore, 2017.

[111] L. Van Ginneken, E. Meers, R. Guisson, A. Ruttens, K. Elst, F.M.G. Tack, J. Vangronsveld, L. Diels, W. Dejonghe, Phytoremediation for heavy metal-contaminated soils combined with bioenergy production, Journal of Environmental Engineering and Landscape Management, 15 (2007) 227-236.

[112] S. Raghu, R.C. Anderson, C.C. Daehler, A.S. Davis, R.N. Wiedenmann, D. Simberloff, R.N. Mack, Adding biofuels to the invasive species fire?, Science, 313 (2006) 1742.

[113] R.N. Mack, D. Simberloff, W.M. Lonsdale, H. Evans, M. Clout, F.A. Bazzaz, Biotic invasions: Causes, epidemiology, global consequences, and control, Ecological Applications, 10 (2000) 689-710.

[114] P. Martin, Killing us softly: Australia's green stalkers: a call to action on invasive plants, and a way forward, Cooperative Research Centre for Australian Weed Management, Adelaide, 2003. 


\section{NEDOSTACI ZELJASTIH ULJARICA KAO SIROVINE U PROIZVODNJI BIODIZELA}

Marija B. Tasic

Tehnološki fakultet, Univerzitet u Nišu, Leskovac, Srbija
(PREGLEDNI RAD)

UDK 662.756.3: 633.85

DOI: $10.5937 /$ savteh2002088T
Uzgoj nejestivih uljarica kao suplementa sirovini za proizvodnju biodizela može agresivno uticati na životnu sredinu. Nejestive zeljaste uljarice su značajno favorizovane kao idealna sirovina za biodizel, iako se malo zna o njihovoj isplatvosti korišćena na industrijskom nivou i uticaju na životnu sredinu. Stavke sa najvećom osetljivošću na kapitalne troškove i ekologiju su otkup zemljišta, životni ciklus biljaka, mehanička berba, đubrivo, suzbijanje korova, štetočina i bolesti, prinos semena i sadržaj ulja. Cilj ovog istraživanja je analizirati nedostatke zeljastih nejestivih uljarica i predložiti prekid njihovog industrijskog uzgoja za proizvodnju biodizela. Izvor informacija za pravilan odabir nejestivih uljarica kao sirovine za proizvodnju biodizela bila je referalna naučna literatura novijeg izdanja. Rezultati ovog istraživanja pokazali su da su zeljaste nejestive uljarice imale visok korovski, ali nizak prinos ulja i potencijal fitoremedijacije. Zauzimali su velike obradive površine dok su zahtevali teže uslove obrade. Nejestive drvenaste uljarice pokazale su se povoljnijim sirovinama za proizvodnju biodizela. Međutim, i kod drvenastih uljarica mora se voditi računa o korovskom potencijalu da bi se sprečila njihova invazivnost.
Ključne reči: biodizel; nejestivo ulje; zeljaste uljarice; drveće; fitoremedijacija; korov. 